\title{
Physicochemical properties, gross composition, energy value and nitrogen fractions of Haflinger nursing mare milk throughout 6 lactation months
}

\author{
Primo Mariani, Andrea Summer*, Francesca MartuzZI, \\ Paolo Formaggioni, Alberto SABbioni, Antonio Lucio Catalano \\ Dipartimento di Produzioni Animali, Biotecnologie Veterinarie, \\ Qualità e Sicurezza degli Alimenti, Sezione di Scienze Zootecniche e Qualità delle Produzioni Animali, \\ Università degli Studi di Parma, Via del Taglio 8, 43100 Parma, Italy
}

(Received 15 March 2001; accepted 3 August 2001)

\begin{abstract}
The trends of the physicochemical properties, chemical constituents and main nitrogen fractions of Haflinger mare milk were studied. Milk samples were collected at d 4, 20, 40, 60, 80, 120, 150 and 180 post-partum, by hand-milking from 5 mares, 7-14 years old (4-11 parities) and 400-490 kg live weight. Density, $\mathrm{pH}$, titratable acidity, fat, protein, lactose and ash varied significantly during the first lactation period, while the freezing point showed statistically no significant modifications. The contents of fat, protein and ash diminished. In addition, the gross energy value tended to decrease and the lactose content increased. Total $\mathrm{N}$ content decreased significantly $(P<0.0001)$, especially between $\mathrm{d} 4(515 \mathrm{mg})$ and $\mathrm{d} 40(286 \mathrm{mg})$ and, to a lesser degree, until d 180 of lactation $\left(255 \mathrm{mg} \cdot 100 \mathrm{~g}^{-1}\right.$ milk). The casein number varied significantly $(P<0.001)$, particularly between the beginning (56.32\%) and the end (45.40\%) of lactation. The trend of non-protein $\mathrm{N}$ and globulin $\mathrm{N}$ fractions was different; both the 2 nd and 3rd month showed the lowest values of the entire lactation $(P<0.05)$. The non-protein N proportion $(\mathrm{NPN} \times 100 /$ total $\mathrm{N})$ increased significantly $(P<0.001)$ from the beginning $(7.74 \%$ at $\mathrm{d} 4)$ to the end $(12.37 \%$ at $\mathrm{d} 180)$ of lactation. The globulin $\mathrm{N}$ proportion increased from the end of the 4th lactation month, reaching in the final period an average value of about $10 \%$ of total $\mathrm{N}$, but with an irregular trend $(P>0.05)$.
\end{abstract}

Haflinger horse / nursing mare / lactation stage / milk properties / milk composition / nitrogen fractions

Résumé - Propriétés physico-chimiques, composition chimique, valeur énergétique et fractions azotées du lait de jument de race Haflinger pendant 6 mois de lactation. L'évolution des propriétés physico-chimiques, des constituants chimiques et des principales fractions azotées du lait de jument de race Haflinger a été étudiée. Les prélèvements de lait ont été effectués à 4, 20, 40, 60, 80, 120, 150

* Correspondence and reprints

e-mail: summer @ unipr.it 
et 180 jours après la mise-bas. Les échantillons de lait ont été prélevés manuellement sur 5 juments, ayant un âge de 7 à 14 ans (4 à 11 mises-bas) et un poids vif de 400 à $490 \mathrm{~kg}$. La densité, le pH, l'acidité de titration, la matière grasse, les matières azotées, le lactose et les cendres ont varié de façon significative pendant la première période de lactation ; tandis que le point de congélation n'a pas été significativement modifié. Les teneurs en matières azotées, matière grasse et cendres ont été diminuées, de même que la valeur énergétique ; en revanche, la teneur en lactose a augmenté. La teneur en azote total a diminué significativement $(P<0,0001)$, notamment entre le $4^{\mathrm{e}}\left(515 \mathrm{mg} \cdot 100 \mathrm{~g}^{-1}\right.$ de lait $)$ et le $40^{\mathrm{e}}\left(286 \mathrm{mg} \cdot 100 \mathrm{~g}^{-1}\right.$ de lait $)$ jour de lactation et, dans une moindre mesure, jusqu' au $180^{\mathrm{e}}$ jour de lactation $\left(255 \mathrm{mg} \cdot 100 \mathrm{~g}^{-1}\right.$ de lait). La proportion de caséine dans les matières azotées totales a varié significativement $(P<0,001)$, surtout entre le début $(56,32 \%)$ et la fin $(45,40 \%)$ de la lactation. L'évolution des fractions d'azote non-protéique (NPN) et d'azote des globulines a été différente ; toutes les deux ont eu les valeurs les plus faibles le $2^{\mathrm{e}}$ et le $3^{\mathrm{e}}$ mois de lactation $(P<0,05)$. La proportion d'azote non-protéique dans les matières azotées totales a augmenté significativement $(P<0,001)$ du début (7,74 \% à 4 jours) à la fin (12,37\% à 180 jours) de la lactation. La proportion de globulines dans les matières azotées totales a augmenté à partir de la fin du $4^{\mathrm{e}}$ mois de lactation, jusqu'à une valeur moyenne d'environ $10 \%$ de l'azote total (mais avec une évolution irrégulière, $P>0,05$ ) en fin de lactation.

cheval Haflinger / jument / stade de la lactation / propriétés du lait / composition du lait / fractions azotées

\section{INTRODUCTION}

The foal, in the various phases of the suckling period, has at its disposal milk amounts that are sufficiently defined [6, 20], but rather variable [12], usually increasing during the first weeks of life. The availability of the nutrients also varies considerably in relation to the evolution of milk composition during the lactation cycle [13, $14,38]$.

Today, there is little information available on the evolution of milk composition (in particular on the plastic and energy value of milk) during lactation. There are some contrasting indications, for example, on the trend of fat content, as well as on the degree of protein and salt impoverishment, also in correspondence with the most tricky phases of development of the foal $[13,17$, $18,28,40]$.

In particular, the knowledge on the evolution of protein composition is partially lacking [28], especially concerning some specific proteins, such as the whey proteins [30], and sometimes also controversial, as, for example, in the case of casein content
$[14,28,41]$. From this point of view, the first research of Minieri and Intrieri [31] has to be considered as fundamental. Among other studies, some of them consider only the first lactation stages [for example: 4, 9, 10, 16, 29, 34], others, instead, consider total protein variations almost exclusively [for example: 3, 6, 19, 23, 33, 38, 42]. This subject has also been studied by other researchers [39, 43, 44].

The aim of this work was to contribute to the knowledge of the variations of the main characteristics of the Haflinger nursing mare milk. Particular attention was paid to the nitrogen fractions and how they evolve throughout 6 months of lactation.

\section{MATERIALS AND METHODS}

The research was carried out on individual milk samples of 5 nursing mares of the Haflinger Horse breed, reared in a stud in the Brescia province (Northern Italy). The mares, from 7 to 14 years of age (4-11 parities), with live weights between 400 and $490 \mathrm{~kg}$, were kept indoors and fed mainly 
perennial rye-grass and hay, and lesser amounts of lucerne grass and hay, all ad libitum. Concentrate was given occasionally, in moderate quantities (max. $3 \mathrm{~kg}$ ), only to some mares during the 1 st and 4th/5th lactation months. The deliveries were all regular, with 2 occurring in March, 2 in April and 1 in May. Milk samplings (8 per mare) were collected at d 4, 20, 40, $60,80,120,150$ and 180 post-partum, for an overall collection of 40 individual samples. Milk was taken by hand-milking from a single mammary gland milked as deep as possible, in presence of the foal, that was previously prevented from suckling for 1-2 hours by a muzzle.

The following analyses were carried out on the single milk samples: $\mathrm{pH}$ with a potentiometer, titratable acidity ( $\left.{ }^{\circ} \mathrm{SH}\right)$ with $0.25 \mathrm{~N}$ $\mathrm{NaOH}$ according to the Soxhlet-Henkel method [1], density at $15^{\circ} \mathrm{C}$ by means of a Quevenne lactometer, freezing point by a thermistor cryoscope, fat and lactose by means of mid infrared spectrophotometry [5] with a Milko-Scan 134A/B, and ash on $20 \mathrm{~g}$ milk at $530{ }^{\circ} \mathrm{C}$.

In addition, the following nitrogen fractions were determined by means of Kjeldahl: total N (TN) on milk, non-casein N (NCN) on acid whey at $\mathrm{pH} 4.6$ and non-protein $\mathrm{N}$ (NPN) on $12 \%$ TCA filtrate of milk according to Aschaffenburg and Drewry [2] and globulin N (Glob N) according to Rowland [35]. The following variables were obtained from these nitrogen fractions: casein $\mathrm{N}$ $(\mathrm{CN}=\mathrm{TN}-\mathrm{NCN})$, casein $(\mathrm{CN} \times 6.38)$, casein number $(\mathrm{CN} \times 100 / \mathrm{TN})$, NPN index $(\mathrm{NPN} \times 100 / \mathrm{TN})$ and globulin $\mathrm{N}$ index (Glob N $\times$ 100/TN).

Gross energy $\left(\mathrm{kcal} \cdot \mathrm{kg}^{-1}\right)$ was calculated with the coefficients reported by Doreau et al. [17], in particular 8.97 for fat, 5.25 for protein and 4.10 for lactose.

Data were analysed by two way ANOVA (fixed effect: lactation stage; random effect: mare) and least significant difference test application.

\section{RESULTS AND DISCUSSION}

\subsection{Physicochemical properties}

The density, starting from the 4th day post-partum to the 60th lactation day, decreased from 1.038 to 1.035 (Tab. I). During the same period, the freezing point also varied (from -0.536 to $-0.520{ }^{\circ} \mathrm{C}$ ) tending towards the freezing point of water. In the following phases, until the 180th lactation day, the values of these two properties tended to have a constant trend, precisely about 1.035 for density and $-0.524{ }^{\circ} \mathrm{C}$ for the freezing point.

Milk produced near the partum had a low $\mathrm{pH}(6.60)$ and a fairly high titratable acidity (6.08 ${ }^{\circ} \mathrm{SH}$ at the 4 th day). During the following 2-3 weeks, the values of both properties varied deeply: $\mathrm{pH}$ markedly increased (6.93) and titratable acidity drastically decreased (3.40 ${ }^{\circ} \mathrm{SH}$ at 20th day) (Fig. 1). In the following phases of lactation the variations were moderate, but sufficient to indicate a tendency of a $\mathrm{pH}$ increase (7.11) and a titratable acidity decrease $\left(2.01{ }^{\circ} \mathrm{SH}\right.$ at 180th day). The $\mathrm{pH}$ value at $\mathrm{d} 4$ is in good agreement with those observed by Johnston et al. [22] during the first two weeks of lactation. For titratable acidity values, there is substantial agreement with Storch [41], but not with the observations of Kulisa [24], who reported a quite different trend, characterised by a considerable increase of the titratable acidity values from the 60 th $\left(2.83{ }^{\circ} \mathrm{SH}\right)$ to the 150th lactation day $\left(3.61{ }^{\circ} \mathrm{SH}\right)$.

\subsection{Gross composition}

Also for the chemical components, the most important variations were registered between the 4th and the 20th/40th lactation day (Tab. I, Fig. 1). All the main constituents decreased, except lactose, which, on the contrary, increased. On the 20th lactation day, more significant variations were registered both for fat $(-37 \%)$ and crude protein $(-32 \%)$, as well as for ash $(-18 \%)$ and 
Table I. Physicochemical properties of Haflinger mare milk in relation to the lactation stage (5 mares; 8 samplings per mare).

\begin{tabular}{|c|c|c|c|c|c|c|c|c|c|}
\hline Lactation stage (d) & 4 & 20 & 40 & 60 & 80 & 120 & 150 & 180 & $P$ \\
\hline \multirow[t]{2}{*}{ Density at $15^{\circ} \mathrm{C}$} & ${ }^{1} 1.0377^{\mathrm{c}}$ & $1.0361^{\mathrm{b}}$ & $1.0353^{\mathrm{ab}}$ & $1.0346^{\mathrm{a}}$ & $1.0352^{\mathrm{ab}}$ & $1.0346^{\mathrm{a}}$ & $1.0346^{\mathrm{a}}$ & $1.0345^{\mathrm{a}}$ & \multirow[t]{2}{*}{$* * *$} \\
\hline & ${ }^{2} 0.0014$ & 0.0008 & 0.0011 & 0.0010 & 0.0007 & 0.0007 & 0.0011 & 0.0009 & \\
\hline \multirow{2}{*}{$\begin{array}{l}\text { Freezing point } \\
\left(\Delta^{\circ} \mathrm{C}\right)\end{array}$} & 0.536 & 0.530 & 0.528 & 0.520 & 0.525 & 0.524 & 0.525 & 0.523 & \multirow[t]{2}{*}{ NS } \\
\hline & 0.013 & 0.008 & 0.006 & 0.018 & 0.010 & 0.008 & 0.011 & 0.016 & \\
\hline \multirow[t]{2}{*}{ pH } & $6.60^{\mathrm{a}}$ & $6.93^{\mathrm{bc}}$ & $7.01^{\mathrm{bc}}$ & $6.88^{\mathrm{b}}$ & $6.92^{\mathrm{b}}$ & $7.03^{\mathrm{bc}}$ & $7.02^{\mathrm{bc}}$ & $7.11^{\mathrm{c}}$ & \multirow[t]{2}{*}{$* * *$} \\
\hline & 0.11 & 0.12 & 0.19 & 0.05 & 0.14 & 0.15 & 0.17 & 0.18 & \\
\hline \multirow{2}{*}{$\begin{array}{l}\text { Titratable acidity } \\
\left({ }^{\circ} \mathrm{SH}\right)\end{array}$} & $6.08^{\mathrm{d}}$ & $3.40^{\mathrm{c}}$ & $2.82^{\mathrm{bc}}$ & $2.82^{\mathrm{bc}}$ & $2.76^{\mathrm{b}}$ & $2.31^{\mathrm{ab}}$ & $2.48^{\mathrm{ab}}$ & $2.01^{\mathrm{a}}$ & \multirow[t]{2}{*}{$* * * *$} \\
\hline & 0.68 & 0.45 & 0.63 & 0.39 & 0.49 & 0.41 & 0.51 & 0.16 & \\
\hline \multirow[t]{2}{*}{ Fat $\left(\mathrm{g} \cdot 100 \mathrm{~g}^{-1}\right)$} & $1.66^{\mathrm{c}}$ & $1.04^{\mathrm{b}}$ & $0.82^{\mathrm{ab}}$ & $0.72^{\mathrm{ab}}$ & $0.53^{\mathrm{a}}$ & $0.62^{\mathrm{ab}}$ & $0.60^{\mathrm{ab}}$ & $0.44^{\mathrm{a}}$ & \multirow[t]{2}{*}{$* * *$} \\
\hline & 0.45 & 0.59 & 0.36 & 0.22 & 0.17 & 0.45 & 0.07 & 0.10 & \\
\hline \multirow{2}{*}{$\begin{array}{l}\text { Protein }(\mathrm{N} \times 6.38) \\
\left(\mathrm{g} \cdot 100 \mathrm{~g}^{-1}\right)\end{array}$} & $3.29^{c}$ & $2.23^{\mathrm{b}}$ & $1.82^{\mathrm{a}}$ & $1.77^{\mathrm{a}}$ & $1.74^{\mathrm{a}}$ & $1.64^{\mathrm{a}}$ & $1.69^{\mathrm{a}}$ & $1.63^{\mathrm{a}}$ & \multirow[t]{2}{*}{$* * * *$} \\
\hline & 0.24 & 0.23 & 0.17 & 0.14 & 0.13 & 0.16 & 0.41 & 0.28 & \\
\hline \multirow[t]{2}{*}{ Lactose $\left(\mathrm{g} \cdot 100 \mathrm{~g}^{-1}\right)$} & $6.36^{\mathrm{a}}$ & $6.65^{\mathrm{b}}$ & $6.78^{\mathrm{bc}}$ & $6.80^{\mathrm{bc}}$ & $6.86^{\mathrm{c}}$ & $6.88^{\mathrm{c}}$ & $6.85^{\mathrm{c}}$ & $6.88^{\mathrm{c}}$ & \multirow[t]{2}{*}{$* * * *$} \\
\hline & 0.02 & 0.08 & 0.16 & 0.20 & 0.08 & 0.21 & 0.13 & 0.14 & \\
\hline \multirow[t]{2}{*}{$\operatorname{Ash}\left(g \cdot 100 g^{-1}\right)$} & $0.57^{\mathrm{e}}$ & $0.47^{\mathrm{d}}$ & $0.39^{c}$ & $0.33^{\mathrm{b}}$ & $0.29^{\mathrm{ab}}$ & $0.28^{\mathrm{ab}}$ & $0.27^{\mathrm{a}}$ & $0.27^{\mathrm{a}}$ & \multirow[t]{2}{*}{$* * * *$} \\
\hline & 0.04 & 0.04 & 0.02 & 0.03 & 0.02 & 0.01 & 0.08 & 0.06 & \\
\hline
\end{tabular}

1,2 Mean values and standard deviation.

a, b, c, d, e Different letters correspond to significantly different averages for $P<0.05$.

NS: not significant; *** $P<0.001 ; * * * * P<0.0001$.

lactose $(+5 \%)$. Crude protein and ash further decreased significantly, also on the 40th lactation day $(-18 \%$ and $-17 \%$, with respect to the 20th day).

Fat content rather rapidly decreased during the first 60/80 days (Fig. 1). Subsequently there was a little increase of the values until the 140th-160th day. The minimum value of the entire lactation was reached on the 180th day (from 1.66 to $0.44 \mathrm{~g}$ per $100 \mathrm{~g}$; decrease $73 \%)$. Such variations agree with data reported in the literature $[6,21,28,32,42]$ for lactations with a duration of at least 4 months. In other cases, more moderate variations, or rather irregular trends [20, 41], have been observed. The fat content increase, recorded at the 4 th $/ 5$ th month, agrees with the observations of Kulisa [25] and Brzeski and Kulisa [7].

Protein content, instead, progressively decreased during the entire lactation (from 3.29 to $1.63 \mathrm{~g}$ per $100 \mathrm{~g}$; decrease $50 \%$ ). Such a protein impoverishment of milk is confirmed by several authors [3, 20, 28, 31, $42]$, while in other studies the variations appear to be more gradual $[6,11,25,27$, 40], or rather irregular [41].

The trend of ash content was rather analogous, although in the first phases of lactation it showed a less accentuated decrease (from 0.57 to $0.27 \mathrm{~g}$ per $100 \mathrm{~g}$; decrease $53 \%$ ) than that of protein content. This trend is substantially confirmed by other observations [6, 21, 28, 32, 37, 42]. 


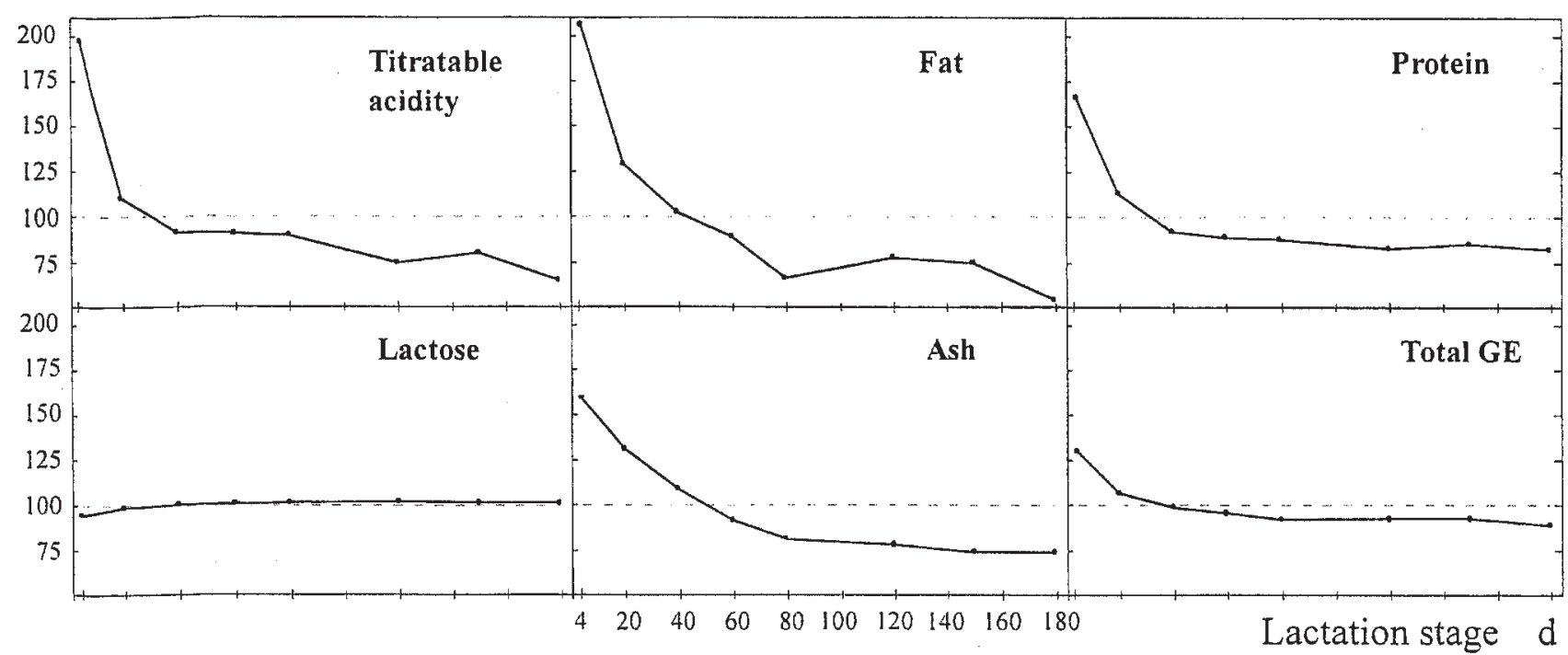

Figure 1. Variations of milk characteristics of Haflinger mares in relation to the lactation stage ( 5 mares; 8 samplings per mare); GE = gross energy; mean value of the 8 periods $=100$. 
Lactose content, on the contrary, in particular during the first lactation weeks, partially counterbalanced the losses of fat and protein. During the whole lactation it varied from 6.36 to $6.88 \mathrm{~g}$ per $100 \mathrm{~g}$ of milk. Several studies tend to confirm that during lactation mare milk becomes rich in carbohydrates $[6,21,26,28,32,40,42]$, even though some authors have found different results $[23,25]$. At the end of lactation (5th month), Kulisa [26] registered a decrease of lactose that confirms the observations of Krasnova [23] relative to the 4th/6th month; this fact, however, is in contrast with Sonntag et al. [40], who found markedly increasing lactose values at the end of lactation.

\subsection{Gross energy}

The variations of the energy value of milk reflected those relative to organic components, precisely protein and fat that decreased and lactose that increased (Tab. II, Fig. 1). Total energy significantly decreased between the 4th and 20th day $(-17 \%)$, but registered a further decrease (statistically not significant) on the 40th day $(-7 \%)$. From the 4 th to 180 th lactation day, the milk energy value, despite the higher contribution of lactose, decreased progressively from 582 to $407 \mathrm{kcal}$ per kg (decrease 30\%). Such variations are in agreement with the observations of Ullrey et al. [42], Burns et al. [8] and Mariani et al. [28]. Analogous indications, but relative only to the first 2 months of lactation, have also been reported by Oftedal et al. [34], Doreau et al. [14] and Martin et al. [29], while Doreau et al. [15], in the same period, did not find any considerable variation.

\subsection{Nitrogen fractions}

Nitrogen composition was modified deeply during lactation (Tab. III). Total N content diminished, as already indicated for crude protein. This trend was amply confirmed by other observations, specifically by lactations lasting at least 5-6 months [20, $31,32]$; in other cases the variation results were more gradual $[6,11]$.

The trends of non-casein $\mathrm{N}$ and casein $\mathrm{N}$ contents were similar, at least until d 150 of lactation. At d 180 there was an increase of the values of non-casein $\mathrm{N}$ and a decrease of those of casein N. Relative variations

Table II. Energy value of Haflinger mare milk in relation to the lactation stage (5 mares; 8 samplings per mare).

\begin{tabular}{lccccccccc}
\hline Lactation stage (d) & 4 & 20 & 40 & 60 & 80 & 120 & 150 & 180 & $P$ \\
\hline Total GE & $582.2^{\mathrm{c}}$ & $482.9^{\mathrm{b}}$ & $447.4^{\mathrm{ab}}$ & $436.0^{\mathrm{a}}$ & $420.5^{\mathrm{a}}$ & $424.2^{\mathrm{a}}$ & $424.0^{\mathrm{a}}$ & $406.8^{\mathrm{a}}$ & $* * * *$ \\
$\left(\mathrm{kcal}^{-1} \mathrm{~kg}^{-1}\right)$ & 40.0 & 56.6 & 28.6 & 19.0 & 18.3 & 49.6 & 15.8 & 19.1 & \\
GE fat/total GE & $25.31^{\mathrm{c}}$ & $18.57^{\mathrm{bc}}$ & $16.23^{\mathrm{ab}}$ & $14.66^{\mathrm{ab}}$ & $11.25^{\mathrm{a}}$ & $12.52^{\mathrm{ab}}$ & $12.80^{\mathrm{ab}}$ & $9.60^{\mathrm{a}}$ & $* *$ \\
$(\%)$ & 5.37 & 8.22 & 6.38 & 4.03 & 3.42 & 7.96 & 1.50 & 1.89 & \\
GE prot./total GE & $29.72^{\mathrm{c}}$ & $24.36^{\mathrm{b}}$ & $21.42^{\mathrm{ab}}$ & $21.28^{\mathrm{ab}}$ & $21.80^{\mathrm{ab}}$ & $20.34^{\mathrm{a}}$ & $20.87^{\mathrm{a}}$ & $20.92^{\mathrm{a}} * * * *$ \\
$(\%)$ & 2.71 & 2.87 & 2.01 & 1.99 & 1.74 & 1.40 & 4.40 & 2.78 \\
GE lact./total GE & $45.01^{\mathrm{a}}$ & $57.07^{\mathrm{b}}$ & $62.34^{\mathrm{bc}}$ & $64.06^{\mathrm{cd}}$ & $66.96^{\mathrm{cd}}$ & $67.14^{\mathrm{cd}}$ & $66.34^{\mathrm{cd}}$ & $69.48^{\mathrm{d}} * * * *$ \\
$(\%)$ & 3.23 & 6.18 & 4.99 & 2.97 & 2.24 & 6.87 & 3.27 & 3.87 \\
\hline
\end{tabular}

1,2 Mean values and standard deviation.

a, b, c, d Different letters correspond to significantly different averages for $P<0.05$

** $P<0.01 ; * * * * P<0.0001$. 
Table III. Nitrogen fraction variations of milk from Haflinger mares in relation to lactation stage (5 mares; 8 samplings per mare).

\begin{tabular}{|c|c|c|c|c|c|c|c|c|c|}
\hline Lactation stage (d) & 4 & 20 & 40 & 60 & 80 & 120 & 150 & 180 & $P$ \\
\hline $\mathrm{CN}\left(\mathrm{mg} \cdot 100 \mathrm{~g}^{-1}\right)$ & $\begin{array}{l}1289.8^{d} \\
216.7\end{array}$ & $\begin{array}{c}179.5^{\mathrm{c}} \\
16.7\end{array}$ & $\begin{array}{c}143.1^{\mathrm{b}} \\
16.0\end{array}$ & $\begin{array}{c}139.5^{\mathrm{ab}} \\
15.7\end{array}$ & $\begin{array}{c}137.9^{\mathrm{ab}} \\
8.9\end{array}$ & $\begin{array}{c}121.9^{\mathrm{ab}} \\
13.9\end{array}$ & $\begin{array}{c}134.5^{\mathrm{ab}} \\
29.0\end{array}$ & $\begin{array}{c}115.6^{\mathrm{a}} \\
18.6\end{array}$ & $* * * *$ \\
\hline $\mathrm{NCN}\left(\mathrm{mg} \cdot 100 \mathrm{~g}^{-1}\right)$ & $\begin{array}{c}225.2^{\mathrm{c}} \\
20.7\end{array}$ & $\begin{array}{c}169.3^{b} \\
21.4\end{array}$ & $\begin{array}{c}142.5^{\mathrm{ab}} \\
11.0\end{array}$ & $\begin{array}{c}137.2^{\mathrm{ab}} \\
10.7\end{array}$ & $\begin{array}{c}135.5^{\mathrm{a}} \\
16.6\end{array}$ & $\begin{array}{c}134.8^{\mathrm{a}} \\
29.7\end{array}$ & $\begin{array}{c}131.1^{\mathrm{a}} \\
37.4\end{array}$ & $\begin{array}{c}139.5^{\mathrm{ab}} \\
25.6\end{array}$ & $* * * *$ \\
\hline Glob N (mg.100 $\left.\mathrm{g}^{-1}\right)$ & $\begin{array}{c}39.5^{\mathrm{b}} \\
2.0\end{array}$ & $\begin{array}{c}28.3^{\mathrm{ab}} \\
7.3\end{array}$ & $\begin{array}{r}21.2^{\mathrm{a}} \\
6.8\end{array}$ & $\begin{array}{c}19.6^{\mathrm{a}} \\
8.8\end{array}$ & $\begin{array}{c}18.9^{\mathrm{a}} \\
6.6\end{array}$ & $\begin{array}{l}26.1^{\mathrm{a}} \\
15.1\end{array}$ & $\begin{array}{l}22.4^{\mathrm{a}} \\
10.2\end{array}$ & $\begin{array}{c}28.8^{\mathrm{ab}} \\
9.4\end{array}$ & $*$ \\
\hline NPN (mg.100 g ${ }^{-1}$ ) & $\begin{array}{c}39.7^{\mathrm{b}} \\
1.8\end{array}$ & $\begin{array}{c}34.5^{\mathrm{ab}} \\
7.3\end{array}$ & $\begin{array}{c}28.0^{\mathrm{a}} \\
2.7\end{array}$ & $\begin{array}{c}29.4^{\mathrm{a}} \\
3.1\end{array}$ & $\begin{array}{c}28.9^{\mathrm{a}} \\
4.9\end{array}$ & $\begin{array}{c}31.0^{\mathrm{a}} \\
6.5\end{array}$ & $\begin{array}{c}31.2^{\mathrm{a}} \\
6.1\end{array}$ & $\begin{array}{c}31.1^{\mathrm{a}} \\
4.6\end{array}$ & $*$ \\
\hline $\mathrm{CN} / \mathrm{TN}(\%)$ & $\begin{array}{c}56.32^{\mathrm{c}} \\
1.07\end{array}$ & $\begin{array}{c}51.53^{\mathrm{b}} \\
2.23\end{array}$ & $\begin{array}{c}50.03^{\mathrm{b}} \\
1.35\end{array}$ & $\begin{array}{c}50.35^{\mathrm{b}} \\
2.80\end{array}$ & $\begin{array}{c}50.53^{\mathrm{b}} \\
3.14\end{array}$ & $\begin{array}{c}47.84^{\mathrm{ab}} \\
6.71\end{array}$ & $\begin{array}{c}51.03^{\mathrm{b}} \\
3.78\end{array}$ & $\begin{array}{c}45.40^{\mathrm{a}} \\
1.54\end{array}$ & $* * *$ \\
\hline NPN/TN (\%) & $\begin{array}{l}7.74^{\mathrm{a}} \\
0.62\end{array}$ & $\begin{array}{l}9.93^{b} \\
2.08\end{array}$ & $\begin{array}{l}9.90^{\mathrm{b}} \\
1.54\end{array}$ & $\begin{array}{c}10.66^{\mathrm{bc}} \\
1.12\end{array}$ & $\begin{array}{c}10.54^{\mathrm{bc}} \\
1.22\end{array}$ & $\begin{array}{c}12.02^{\mathrm{bc}} \\
1.90\end{array}$ & $\begin{array}{c}11.85^{\mathrm{bc}} \\
0.87\end{array}$ & $\begin{array}{c}12.37^{c} \\
2.00\end{array}$ & $* * *$ \\
\hline NPN/NCN (\%) & $\begin{array}{c}17.74^{\mathrm{a}} \\
1.79\end{array}$ & $\begin{array}{c}20.41^{\mathrm{abc}} \\
3.72\end{array}$ & $\begin{array}{c}19.81^{\mathrm{ab}} \\
3.08\end{array}$ & $\begin{array}{l}21.57^{\mathrm{abc}} \\
2.85\end{array}$ & $\begin{array}{c}21.29^{a b c} \\
1.60\end{array}$ & $\begin{array}{c}23.06^{\mathrm{bc}} \\
2.45\end{array}$ & $\begin{array}{c}24.28^{c} \\
2.21\end{array}$ & $\begin{array}{c}22.73^{b c} \\
4.22\end{array}$ & * \\
\hline Glob N/TN (\%) & $\begin{array}{l}7.69 \\
0.47\end{array}$ & $\begin{array}{l}8.04 \\
1.76\end{array}$ & $\begin{array}{l}7.35 \\
1.85\end{array}$ & $\begin{array}{l}7.13 \\
3.32\end{array}$ & $\begin{array}{l}6.85 \\
1.99\end{array}$ & $\begin{array}{l}9.88 \\
4.82\end{array}$ & $\begin{array}{l}8.19 \\
2.86\end{array}$ & $\begin{array}{r}11.30 \\
2.95\end{array}$ & NS \\
\hline Glob N/NCN (\%) & $\begin{array}{r}17.64 \\
1.46\end{array}$ & $\begin{array}{r}16.56 \\
3.57\end{array}$ & $\begin{array}{r}14.74 \\
3.82\end{array}$ & $\begin{array}{r}14.11 \\
5.78\end{array}$ & $\begin{array}{r}13.77 \\
3.56\end{array}$ & $\begin{array}{r}18.72 \\
8.17\end{array}$ & $\begin{array}{r}16.46 \\
4.65\end{array}$ & $\begin{array}{r}20.68 \\
5.22\end{array}$ & NS \\
\hline
\end{tabular}

1,2 Mean values and standard deviation.

a, b, c, d, e different letters correspond to significantly different averages for $P<0.05$.

NS: not significant; * $P<0.05$; *** $P<0.001$; **** $P<0.0001$.

TN: Total N; CN: Casein N; NCN: Non-casein N, Glob N: Globulin N, NPN: Non-protein N.

(mean value $=100)$ of casein $\mathrm{N}$ content were more marked than those of non-casein $\mathrm{N}$ (Fig. 2). The casein content decrease is amply confirmed by the observations of Minieri and Intrieri [31], Mariani et al. [28] and Csapò-Kiss et al. [10], the latter being related to the first two lactation months only. Doreau et al. [14], at early lactation, observed moderate variations; while Storch [41], reported an irregular non-significant trend.

The variations of non-protein $\mathrm{N}$ and globulin $\mathrm{N}$ fractions were different (Tab. III). During the 2nd and 3rd months (d 40, 60 and 80 ), both variables showed the lowest concentrations of the whole lactation period.
Relative variations (mean value $=100$ ) of globulin $\mathrm{N}$ were more marked than those of non-protein $\mathrm{N}$ content which were substantially moderate (Fig. 2). Non-protein $\mathrm{N}$ variations of the milk from the early lactation phases are in agreement with those observed by other authors [10, 14, 28, 29]. Storch [41], however, reported irregular variations for bulk milk samples; while other authors $[33,34]$ did not find significant variations. Globulin $\mathrm{N}$ variations of the first lactation phases are in agreement with those observed by other authors $[4,9,11,31]$. There is no accordance with the trend during the subsequent lactation stages: both Minieri and 


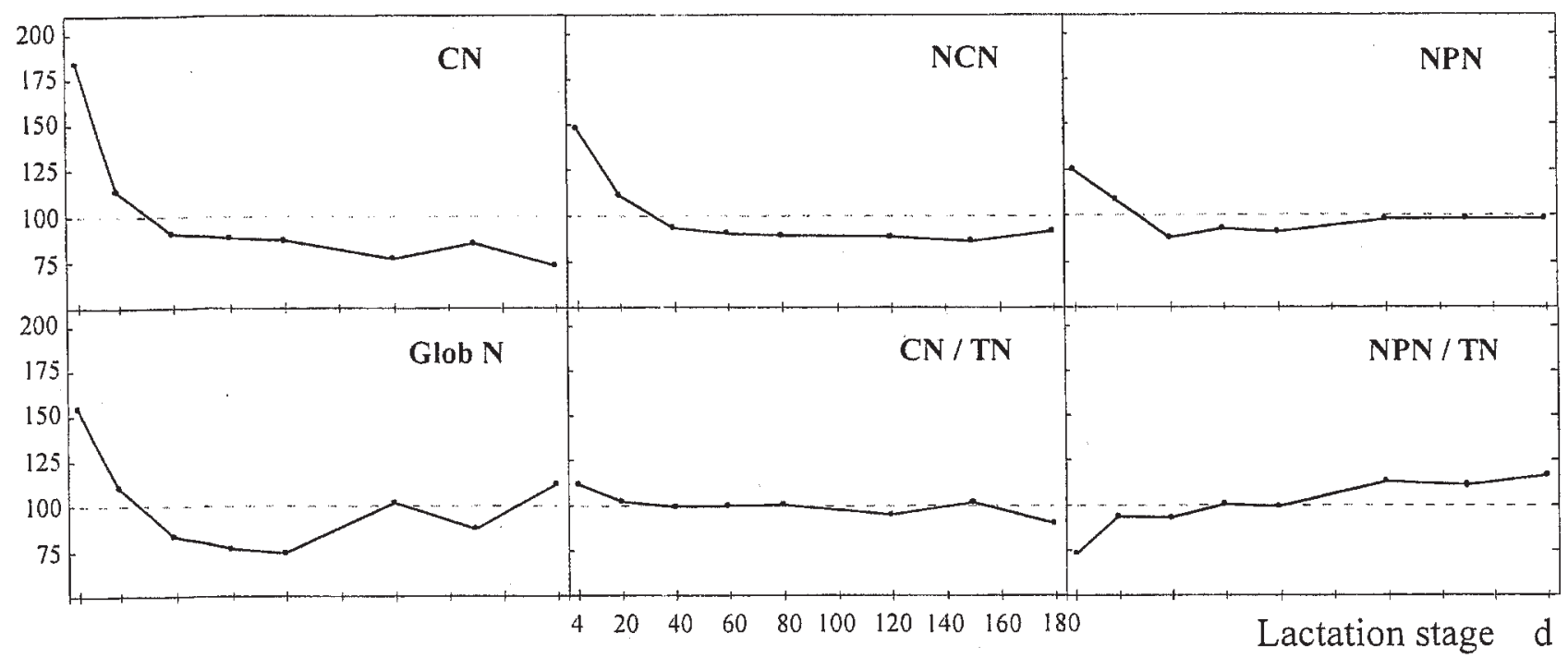

Figure 2. Nitrogen fraction trends throughout six lactation months in Haflinger mare milk ( 5 mares; 8 samplings per mare); for the acronyms see notes of Table III; mean value of the 8 periods $=100$. 
Intrieri [31] and Deskur et al. [11], reported a gradual decrease of globulins towards the 5 th/6th month, which was different from our results.

Moreover, throughout the 6 lactation months, the ratios among nitrogen fractions varied, sometimes significantly.

Casein number $(\mathrm{CN} \times 100 / \mathrm{TN})$, for example, varied significantly (Tab. III). At $\mathrm{d} 4$, casein number $(56.32 \%)$ was higher than that of d 180 of lactation (45.40\%). These variations are in agreement with those reported by Rozhanskii et al. [36] and Mariani et al. [28]. For most authors, excluding colostrum and the short transition phase, the lactation stage does not have a significant effect on the casein number trend $[11,14$, 25, 31]. Minieri and Intrieri [31], for the milk of Haflinger mares, from d 3 to d 180 of lactation, found values that fluctuate only a little around $67.5 \%$. On the contrary, Neseni et al. [32] and Storch [41] observed more variable values, with a tendency to increase in the final period of lactation.

Non-protein $\mathrm{N}$ proportional values, calculated as compared to total $\mathrm{N}$ content $(\mathrm{NPN} \times 100 / \mathrm{TN})$, increased progressively from the beginning $(7.74 \%$ at $\mathrm{d} 4)$ until the end (12.37\% at d 180) of lactation (Tab. III; Fig. 2). The same happened, at least until the 5th lactation month, for the NPN index calculated with reference to non-casein $\mathrm{N}$ content $(\mathrm{NPN} \times 100 / \mathrm{NCN})$, whose values varied between $17.74 \%$ (d 4) and $24.28 \%$ (d 150). The NPN index trend is completely in accordance with what was reported by Neseni et al. [32], Martin et al. [29] and Mariani et al. [28]. Other authors, instead, observed very limited variations, increasing [10, 14, 33], or having rather irregular variations [41].

Globulin N proportional values (for example: Glob $N \times 100 / T N$ ) showed an irregular and non-significant trend (Tab. III). The nonsignificant increase of the Globulin $\mathrm{N}$ index in the advanced stage of lactation is not confirmed by the few observations found in the literature [31, 44]. According to Ustinova et al. [44], immunoglobulins in the first four lactation months represent an almost constant proportion of total whey protein.

\section{CONCLUSIONS}

Physicochemical properties, chemical composition, energy value and nitrogen fractions of Haflinger nursing mare milk were significantly modified during 6 lactation months. The most important variations concerned the initial phases of lactation, deeply affecting the "plastic" and energetic value of milk, which is the only nutritional source for the young foal in full development.

In little more than one month, fat $(-51 \%)$, protein $(-45 \%)$ and ash $(-32 \%)$ contents decreased drastically. Consequently, the energy value of the milk decreased $(-24 \%)$, despite an increase in lactose content. Protein supply, equal to $33 \mathrm{~g}$ per $\mathrm{kg}$ milk at the 4th day, was reduced to $18 \mathrm{~g}$ on the 40th day; likewise, fat supply varied from 17 to 8 grams.

Also nitrogen composition varied markedly; the quantitative variations of our results were preponderant. Between $\mathrm{d} 4$ and d 180 , casein content decreased by $60 \%$ and whey protein content by $38 \%$. This means that important qualitative variations happen, moreover extended to non-protein $\mathrm{N}$ and globulin $\mathrm{N}$ contents, fractions that both showed trends different from those of casein and total whey protein.

From the nutritional point of view, this quite early impoverishment is more noteworthy. This low protein value of milk is very likely to be related to the mares' diet, which, since the beginning of lactation, was based almost exclusively on forage supply.

\section{ACKNOWLEDGEMENTS}

This research program was co-financed by "Università degli Studi di Parma" and "Ministero dell'Università e della Ricerca Scientifica e Tecnologica", 1998. 


\section{REFERENCES}

[1] Anon, Säuregradbestimmung nach SoxhletHenkel (SH), Milchwissenschaft 18 (1963) 520.

[2] Aschaffenburg R., Drewry J., New procedure for the routine determination of the various noncasein proteins of milk, Proceedings of the XVth International Dairy Congress, London, United Kingdom, 3, 1959, pp. 1631-1637.

[3] Ashcraft A., Tyznik W.J., Effect of diet on volume and composition in mare's milk, J. Anim. Sci. 43 (1976) 248 (Abstr.).

[4] Balbierz H., Nikolajczuk M., Poliwoda A., Ruda M., Studies on colostrum and milk whey proteins in mares during nursing, Pol. Arch. Weter. 18 (1975) 455-465.

[5] Biggs D.A., Instrumental infrared estimation of fat, protein and lactose in milk: collaborative study, J. Assoc. Off. Anal. Chem. 61 (1978) 1015-1034

[6] Bouwman H., van der Schee W., Composition and production of milk from Dutch warmblooded saddle horse mares, Z. Tierphysiol Tierernähr. Futtermittelkd. 40 (1978) 39-53.

[7] Brzeski E., Kulisa M., Levels of N-acetylneuraminic acid and fat in milk of Arab mares, Rocz. Nauk. Zootech. 6 (1979) 29-35.

[8] Burns H.D., Gibbs P.G., Potter G.D., Milkenergy production by lactating mares, J. Equine Vet. Sci. 12 (1992) 118-120.

[9] Cauvin E., Sacchi P., Bergero D., Turi R.M., Caratteristiche compositive e livelli di immunoglobine del colostro e del latte di cavalla, Rivista SIDI 3 (1997) 17-22.

[10] Csapó-Kiss Zs., Stefler J., Martin T.G., Makray S., Csapó J., Composition of mares' colostrum and milk. Protein content, amino acid composition and contents of macro- and micro-elements, Int. Dairy J. 5 (1995) 403-415.

[11] Deskur S., Leonhard-Kluz I., Grochowalski K. Rychwalska-Nahlik M., Occurrence of scours in foals during post-partum oestrus in their dams, and composition of milk whey proteins, Rocz. Nauk. Zootech. 5 (1978) 115-127.

[12] Doreau M., Le lait de jument et sa production : particularités et facteurs de variation, Lait 74 (1994) 401-418.

[13] Doreau M., Boulot S., Recent knowledge on mare milk production: a review, Livest. Prod. Sci. 22 (1989) 213-235

[14] Doreau M., Boulot S., Barlet J.-P., PatureauMirand P., Yield and composition of milk from lactating mares: effect of lactation stage and individual differences, J. Dairy Res. 57 (1990) 449-454.

[15] Doreau M., Boulot S., Bauchart D., Barlet J.-P., Martin-Rosset W., Voluntary intake, milk production and plasma metabolites in nursing mares fed two different diets, J. Nutr. 122 (1992) 992-999.

[16] Doreau M., Boulot S., Chilliard Y., Yield and composition of milk from lactating mares: effect of body condition at foaling, J. Dairy Res. 60 (1993) 457-466.

[17] Doreau M., Boulot S., Martin-Rosset W. Robelin J., Relationship between nutrient intake, growth and body composition of the nursing foal, Reprod. Nutr. Dev. 26 (1986) 683-690.

[18] Enbergs H., Willich J., Failling K., Eiweiss-, Glucose- und Lipidgehalt in der Milch von Zuchtstuten im Verlauf der Laktation, Zuchtungskunde 71 (1999) 245-266.

[19] Fuentes-Garcia F., Gonzalo Abascal C., De Castillo Caracuel A., Quiles Sotillo A. Vinuesa Silva M., Preliminary study on composition of the colostrum from mares of Spanish (Andalusian) breed and its evolution to milk, Arch. Zootec. 40 (1991) 153-160.

[20] Gibbs P.G., Potter G.D., Blake R.W., McMullan W.C., Milk production of Quarter Horse mares during 150 days of lactation, J. Anim. Sci. 54 (1982) 496-499.

[21] Intrieri F., Minieri L., Sulla composizione chimica del latte di cavalla: indagini su soggetti di razza Avelignese, Proceedings of the Società Italiana Scienze Veterinarie, Saint Vincent, Aosta, Italy, 23 (1969), pp. 558-561.

[22] Johnston R.H., Kamstra L.D., Kohler P.H. Mare's milk composition as related to "foal heat" scours, J. Anim. Sci. 31 (1970) 549-553.

[23] Krasnova O., Chemical composition of milk from mares foaling at different seasons, Konevodstvo i Konnyi Sport 2 (1962) 27-28.

[24] Kulisa M., The effects of some non-inheritable factors on the composition of the milk of mares in the course of lactation, Zesz. Nauk. WSR, ser. B 61 (1970) 17-28.

[25] Kulisa M., Composition of milk from mares of three breeds with special reference to N-acetylneuraminic acid, Acta Agrar. Silv. Zootech. 17 (1977) 25-37.

[26] Kulisa M., Lactose, free glucose and galactose levels in the milk of Arab mares, Rocz. Nauk. Zootech. 7 (1980) 31-36.

[27] Lukas V.K., Albert W.W., Owens F.N., Peters A., Lactation of Shetland mares, J. Anim. Sci. 34 (1972) 350 (Abstr.).

[28] Mariani P., Martuzzi F., Catalano A.L., Composizione e proprietà fisico-chimiche del latte di cavalla: variazione dei costituenti azotati e minerali nel corso della lattazione, Ann. Fac. Med. Vet., Univ. Parma 13 (1993) 43-58.

[29] Martin R.G., McMeniman N.P., Dowsett K.F. Milk and water intakes of foals sucking grazing mares, Equine Vet. J. 24 (1992) 295-299. 
[30] Martuzzi F., Tirelli A., Summer A., Catalano A.L., Mariani P., Percentage distribution of the main whey proteins in milk of Italian Saddle Horse nursing mares during the first two lactation months, in: van Arendonk J.A.M. (Ed.), Proceedings of the 50th Annual Meeting of the European Association For Animal Production, Zurich, Switzerland, 1999, p. 341 (Abstr.)

[31] Minieri L., Intrieri F., Ricerche elettroforetiche sulle frazioni proteiche del colostro e del latte di cavalle di razza Avelignese in rapporto alla distanza dal parto, Acta Med. Vet. 16 (1970) 73-88.

[32] Neseni R., Flade E., Heidler G., Steger H., Yield and composition of mare's milk in the course of lactation, Arch. Tierzucht. 1 (1958) 91-129.

[33] Oftedal O.T., Jenness R., Interspecies variation in milk composition among horses, zebras and asses (Perissodactyla: Equidae), J. Dairy Res. 55 (1988) 57-66.

[34] Oftedal O.T., Hintz H.F., Schryver H.F., Lactation in the horse: milk composition and intake by foals, J. Nutr. 113 (1983) 2096-2106.

[35] Rowland S.J., The determination of the nitrogen distribution in milk, J. Dairy Res. 9 (1938) 42-46.

[36] Rozhanshií M.O., Sergeeva A.V., Kudryashov A.G., Protein composition of mares' milk, Dokl. Mosk. Sel'-khoz. Akad. Timiryazeva (Zootekhniya) 78 (1962) 188-193.
[37] Schryver H.F., Oftedal O.T., Williams J. Soderholm L.V., Hintz H.F., Lactation in the horse: the mineral composition of mare milk, J. Nutr. 116 (1986) 2142-2147.

[38] Smolders E.A.A., van der Veen N.G., van Polanen A., Composition of horse milk during the suckling period, Livest. Prod. Sci. 25 (1990) 163-171.

[39] Sokhtaev M.K., Composition of milk of Karabair mares, Dokl. Mosk. Sel'-khoz. Akad. Timiryazeva (Zootekhniya) 157 (1970) 211-215.

[40] Sonntag A.C., Enbergs H., Ahlswede L., Elze K., Inhalsstoffe in der Stutenmilch in Abhängigkeit vom Laktationsstadium und verschiedenen Umweltfaktoren, Pferdeheilkunde 12 (1996) 220-222.

[41] Storch G., Composition and properties of mare's milk and Koumiss, with particular regard to dietetic aspects, Thesis, Justus-Liebig-Universität Giessen, Germany, 1985, 98 p.

[42] Ullrey D.E., Struthers R.D., Hendricks D.G., Brent B.E., Composition of mare's milk, J. Anim. Sci. 25 (1966) 217-222.

[43] Urbinisov Zh.K., Servetnik-Chalaya G.K., Izatullaev E.A., Protein content of mares' milk, Molochnaya Promyshlennost' 2 (1981) 45.

[44] Ustinova V., Kazantseva A., Baturina L., Dement'Eva T., Siberian Koumiss, Konevodstvo i Konnyi Sport 4 (1983) 17. 